OPEN ACCESS

Edited by:

Michael J. Haydon,

University of Melbourne, Australia

Reviewed by:

Alexander Arthur Theodore Johnson,

University of Melbourne, Australia

Eva Darko,

Hungarian Academy of Sciences

(MTA), Hungary

*Correspondence:

Peng Wang

p.wang3@njau.edu.cn

Specialty section:

This article was submitted to

Plant Physiology,

a section of the journal

Frontiers in Plant Science

Received: 22 May 2017

Accepted: 24 July 2017

Published: 03 August 2017

Citation:

Kopittke PM, McKenna BA, Karunakaran C, Dynes JJ, Arthur Z,

Gianoncelli A, Kourousias G, Menzies NW, Ryan PR, Wang P, Green K and Blamey FPC (2017) Aluminum Complexation with Malate within the Root Apoplast Differs between Aluminum Resistant and Sensitive Wheat Lines.

Front. Plant Sci. 8:1377.

doi: 10.3389/fpls.2017.01377

\section{Aluminum Complexation with Malate within the Root Apoplast Differs between Aluminum Resistant and Sensitive Wheat Lines}

\author{
Peter M. Kopittke1, Brigid A. McKenna1', Chithra Karunakaran², James J. Dynes², \\ Zachary Arthur', Alessandra Gianoncelli ${ }^{3}$, George Kourousias ${ }^{3}$, Neal W. Menzies', \\ Peter R. Ryan ${ }^{4}$, Peng Wang ${ }^{5,6 *}$, Kathryn Green ${ }^{7}$ and F. P. C. Blamey ${ }^{1}$ \\ ${ }^{1}$ School of Agriculture and Food Sciences, The University of Queensland, Brisbane, QLD, Australia, ${ }^{2}$ Canadian Light Source \\ Inc., Saskatoon, SK, Canada, ${ }^{3}$ Elettra - Sincrotrone Trieste, Trieste, Italy, ${ }^{4} \mathrm{CSIRO}$ Agriculture and Food, Canberra, ACT, \\ Australia, ${ }^{5}$ College of Resources and Environmental Sciences, Nanjing Agricultural University, Nanjing, China, ${ }^{6}$ Centre for \\ Soil and Environmental Research, School of Agriculture and Food Sciences, The University of Queensland, Brisbane, QLD, \\ Australia, ${ }^{7}$ Centre for Microscopy and Microanalysis, The University of Queensland, Brisbane, QLD, Australia
}

In wheat (Triticum aestivum), it is commonly assumed that Al is detoxified by the release of organic anions into the rhizosphere, but it is also possible that detoxification occurs within the apoplast and symplast of the root itself. Using Al-resistant (ET8) and Al-sensitive (ES8) near-isogenic lines of wheat, we utilized traditional and synchrotronbased approaches to provide in situ analyses of the distribution and speciation of Al within root tissues. Some Al appeared to be complexed external to the root, in agreement with the common assumption. However, root apical tissues of ET8 accumulated four to six times more Al than ES8 when exposed to Al concentrations that reduce root elongation rate by 50\% (3.5 $\mu \mathrm{M}$ Al for ES8 and $50 \mu \mathrm{M}$ for ET8). Furthermore, in situ analyses of ET8 root tissues indicated the likely presence of Al-malate and other forms of Al, predominantly within the apoplast. To our knowledge, this is the first time that $\mathrm{X}$-ray absorption near edge structure analyses have been used to examine the speciation of Al within plant tissues. The information obtained in the present study is important in developing an understanding of the underlying physiological mode of action for improved root growth in systems with elevated soluble Al.

Keywords: aluminum toxicity, apoplast, distribution, malate, organic acids, speciation

\section{INTRODUCTION}

Acid soils comprise ca. four billion ha of the global ice-free land or ca. $40 \%$ of the world's arable land (von Uexküll and Mutert, 1995; Eswaran et al., 1997). In acid soils, the increased solubility of Al-containing minerals (Lindsay, 1979) increases $\mathrm{Al}^{3+}$ and Al-hydroxy anions that impact upon many cellular functions (Taylor, 1991). Root apices are the most sensitive part of the root (Ryan et al., 1993) and the apoplast is an important site for Al toxicity (Horst et al., 2010). Most cellular $\mathrm{Al}$ accumulates in the cell wall of the root apices due to the negative charges on the pectic and hemicellulose polysaccharides such as xyloglucans (Taylor et al., 2000; Yang et al., 2011; Zhu et al., 2012). As $\mathrm{Al}^{3+}$ binds to these charges, it stiffens cell walls thereby decreasing their loosening as required for cell elongation (Cosgrove, 1989; Jones et al., 2006; Kopittke et al., 2015). Accumulation 
of $\mathrm{Al}$ in the apoplast can be reduced by chemical changes that decrease charge density in the cell wall. For instance, transgenic plants engineered with greater pectin methylation or greater $\mathrm{O}$-acetylation on the xyloglucan chains accumulate less $\mathrm{Al}$ and are more resistant of $\mathrm{Al}$ stress (Schmohl et al., 2000; Eticha et al., 2005a; Yang et al., 2008; Zhu et al., 2014). The importance of the apoplast in Al toxicity is highlighted by the Nramp aluminum transporter (NRAT1) in rice (Oryza sativa L.) (Xia et al., 2010). This transporter also reduces $\mathrm{Al}$ in the cell wall and increases $\mathrm{Al}$ resistance by vacuolar $\mathrm{Al}$ sequestration in roots cells. However, cell wall stiffening due to the accumulation of $\mathrm{Al}$ in the apoplast is not the only toxic interaction with $\mathrm{Al}^{3+}$ since application of $\mathrm{Al}^{3+}$ specifically to the elongation zone of maize caused considerable damage to the outer tissue layers but did not inhibit root growth (Ryan et al., 1993). Also, Al causes damage intracellularly by affecting $\mathrm{Ca}$ concentrations, interfering with cell division (Doncheva et al., 2005), disrupting the Golgi and mitochondrial functions (Bennet et al., 1985; Yamamoto et al., 2002), and compromising membrane integrity (Yamamoto et al., 2001).

Plant species that accumulate $\mathrm{Al}$ are able to tolerate high concentrations of $\mathrm{Al}$ within their tissues through production of organic acids (including oxalic acid and citric acid) which result in the formation of non-toxic Al-complexes (Ma et al., 1997a,b). In plant species such as wheat (Triticum aestivum) that do not accumulate $\mathrm{Al}$ in foliar tissues, it is proposed that $\mathrm{Al}$ is detoxified by the release of organic anions, particularly malate (Delhaize et al., 1993b; Ma et al., 2001) and citrate (Ryan et al., 2009; Garcia-Oliveira et al., 2014), into the rhizosphere which chelates $\mathrm{Al}$ thereby reducing its toxic effects within the root.

Delhaize et al. (1993b) showed that Al-induced release of malate is the major mechanism of $\mathrm{Al}$ resistance in wheat, with the secretion of malate from wheat roots occurring within 15 min of exposure to $\mathrm{Al}^{3+}$. Furthermore, malate excretion increases with increasing $\mathrm{Al}$ concentration and occurs largely from the apical 3-5 $\mathrm{mm}$ of the root. Much is already known about the release of malate by root apices (Delhaize et al., 1993b, 2007; Ryan et al., 1995a; Pellet et al., 1996; Ma et al., 2001; Kochian et al., 2004; de Andrade et al., 2011). However, Kinraide et al. (2005) noted that although many investigators have stated that $\mathrm{Al}$ resistance results from secretion of organic acid anions into the rhizosphere, there is not much data directly supporting this. Delhaize et al. (2007), furthermore, stated that the organic acid anions likely chelate $\mathrm{Al}$ either in the immediate vicinity of the apoplasm, or even within the apoplasm itself.

Some studies have reported that the concentration of malate in the root apex does not differ between Al-resistant and Al-sensitive near-isogenic lines (NILs) (the NILs differing in their Al-resistance due to the increased production of malate by the resistant NIL relative to the sensitive NIL) (Delhaize et al., 1993b; Ryan et al., 1995a) - this suggests that Al is not complexed by malate within the root tissues. Indeed, the complexation of $\mathrm{Al}$ within the root of the Al-resistant genotype would be expected to result in a higher malate concentration in these Al-resistant cultivars. However, such analyses assume that the selected analytical approach not only measures free malate, but also the Al-malate complex. By contrast, Tian et al. (2013), also using
NILs of wheat, reported that malate in root apices is indeed higher in the Al-resistant genotype relative to the Al-sensitive genotype. Furthermore, when seedlings were exposed to concentrations of $\mathrm{Al}$ that result in the same inhibition of root elongation $(5 \mu \mathrm{M}$ for $\mathrm{Al}$-sensitive genotype and $50 \mu \mathrm{M}$ for Al-resistant genotype), Kikui et al. (2007) reported that two to three times more Al accumulated in the apical tissues of the Al-resistant genotype. This again suggests the possibility that $\mathrm{Al}$ is not only complexed external to the root but also within the root tissues.

To determine whether $\mathrm{Al}$ is complexed within the root itself or within the rhizosphere requires an assessment of both the speciation and distribution of $\mathrm{Al}$ within the root tissue. However, few studies have provided this information for roots of NILs or cultivars that differ in Al-resistance and organic acid production. Rather than examining the speciation of $\mathrm{Al}$ within root tissues, studies have generally examined the concentration of malate, either in solution or within the root tissue. Whilst the concentration of malate is likely to influence the speciation of $\mathrm{Al}$, it is not a measure of $\mathrm{Al}$ speciation per se. The distribution of $\mathrm{Al}$ within root tissues is also important, with Delhaize et al. (1993a) utilizing energy-dispersive X-ray spectroscopy coupled with scanning electron microscopy (SEM-EDS) to examine the distribution of $\mathrm{Al}$ in roots of the two NILs of wheat, ES8 and ET8, for example.

The aim of the present study was to determine whether $\mathrm{Al}$ is present as an Al-malate complex within the root tissues and whether the complexation of $\mathrm{Al}$ by malate influences $\mathrm{Al}$ distribution. We do not question the importance of malate (and other organic anions) in enabling plants to resist elevated levels of $\mathrm{Al}$, but rather, we aimed to investigate whether $\mathrm{Al}$ is complexed by malate externally to the root or within the root itself (or both). We used NILs of wheat, ES8 and ET8, which differ in alleles for TaALMT1 (the major gene for Al resistance that control malate efflux) with a resultant ca. 10fold difference in their tolerance to $\mathrm{Al}$ in nutrient solution experiments. For these NILs, the speciation of $\mathrm{Al}$ within the root apices was analyzed in situ using synchrotron-based X-ray absorption near edge structure (XANES) spectroscopy. Changes in the cellular and sub-cellular distribution of $\mathrm{Al}$ were also analyzed in situ using synchrotron-based low energy X-ray fluorescence (LEXRF) microscopy. It is not the purpose of this study to further examine the kinetics or magnitude of malate production or secretion but rather to investigate the uncertainty of where the malate anion chelates $\mathrm{Al}$ and affords greatest protection: in the rhizosphere as suggested by Ma et al. (2001) and many others or within the root itself (defined here as being either within the apoplast or within the symplast). This study provides information regarding the underlying mechanism whereby organic acids confer resistance to excess $\mathrm{Al}$ in the rooting medium.

\section{MATERIALS AND METHODS}

\section{General Experimental Procedures}

Solution culture experiments were conducted with two NILs, ES8 and ET8, that differ in Al resistance at a single locus, TaALMT1, 
with ET8 having greater malate efflux than ES8 in the presence of Al (Delhaize et al., 1993a). Seeds were placed in rolled paper towel suspended vertically in tap water in a laboratory maintained at $25^{\circ} \mathrm{C}$ (Kopittke et al., 2008). After 2 days, the seedlings were placed on top of a $600 \mathrm{~mL}$ beaker filled to the brim $(650 \mathrm{~mL})$ with $1 \mathrm{mM} \mathrm{CaCl}_{2}$ and $5 \mu \mathrm{M} \mathrm{H}_{3} \mathrm{BO}_{3}$ solution reduced to $\mathrm{pH} 4.6$ using $0.1 \mathrm{M} \mathrm{HCl}$. After ca. $18 \mathrm{~h}$, the seedlings were transferred to the treatment solutions in which $\mathrm{Al}$ was added using appropriate volumes of a $10 \mathrm{mM} \mathrm{AlCl}_{3}$ stock solution. All solutions were adjusted to $\mathrm{pH} 4.6$ and continuously aerated unless otherwise stated.

\section{Dose-Response Curves}

A total of 13 treatments was prepared in $1 \mathrm{mM} \mathrm{CaCl} 2$ and $5 \mu \mathrm{M} \mathrm{H} \mathrm{H}_{3} \mathrm{BO}_{3}$, with seven $\mathrm{Al}$ concentrations for ES8 $(0,2.5,3.5,5,10,25$, and $100 \mu \mathrm{M} \mathrm{Al})$ and six for ET8 $(0,5,10,25,50$, and $100 \mu \mathrm{M})$. Each experimental unit consisted of three seedlings, with each treatment having three replicates. Except for the $100 \mu \mathrm{M}$ treatment at $\mathrm{pH}$ 4.5 , solutions were adjusted to $\mathrm{pH} 4.6$ using $0.1 \mathrm{M} \mathrm{HCl}$ immediately following the addition of Al. Digital photography (Canon SX10IS) was used to allow measurement of root length (Kopittke et al., 2008), with images captured at the time of transfer to the Al-containing solutions $(0 \mathrm{~h})$, and after $6,12,18,24$, and $48 \mathrm{~h}$. Root elongation rate (RER) was calculated following analysis of the images using ImageJ version $1.45 \mathrm{~s}^{1}$.

\section{Bulk Al Concentration in Root Tissues}

A total of 10 treatments were utilized for the measurement of bulk tissue $\mathrm{Al}$ concentrations, with roots of ES8 and ET8 exposed to $0,3.5$, and $50 \mu \mathrm{M} \mathrm{Al}$ for 3 and $48 \mathrm{~h}$. Each experimental unit consisted of two replicates of 15 seedlings. After exposure to $\mathrm{Al}$ for the required periods, the roots were dipped in $1 \mathrm{mM} \mathrm{CaCl} 2$ for 1 min before the root apices $(5 \mathrm{~mm})$ were excised, excess moisture removed using filter paper, and weighed. Tissues were digested using a 5:1 mixture of nitric and perchloric acids before analysis for $\mathrm{Al}$ using inductively coupled plasma optical emission spectroscopy.

\section{Root Tissue Cation Exchange Capacity}

After ca. $18 \mathrm{~h}$ growth in basal solutions, seedlings of ES8 and ET8 were transferred to new solutions containing $1 \mathrm{mM}$ $\mathrm{CaCl}_{2}$ and $5 \mu \mathrm{M} \mathrm{H} \mathrm{H}_{3} \mathrm{BO}_{3}$ (with $0 \mu \mathrm{M}$ Al) for a further 3 h. Each experimental unit consisted of two replicates of 70 seedlings. The cation exchange capacity (CEC) of the apical root tissues was measured using $\mathrm{Cu}$-sorption (Blamey et al., 2014; Meychik et al., 2014). Briefly, seedlings were transferred for $1 \mathrm{~h}$ to a solution of $5 \mu \mathrm{M} \mathrm{CuCl} 2$ at $4{ }^{\circ} \mathrm{C}$ and $\mathrm{pH} 4.6$ to allow $\mathrm{Cu}$ sorption but limit metabolic changes. Adsorption of $\mathrm{Cu}$ binds rapidly and strongly to cell walls of roots (Kopittke et al., 2011) and hence provides an estimate of CEC.

\footnotetext{
${ }^{1}$ http://imagej.nih.gov/ij/
}

\section{Cellular and Subcellular Distribution of Al in Root Tissues}

The cellular and subcellular distribution of $\mathrm{Al}$ was assessed using synchrotron-based LEXRF (Kaulich et al., 2009) in an experiment of six treatments, with both ES8 and ET8 exposed to $3.5 \mu \mathrm{M} \mathrm{Al}$ for either 3 or $48 \mathrm{~h}$, and ET8 also exposed to $50 \mu \mathrm{M} \mathrm{Al}$ for 3 or $48 \mathrm{~h}$. After growth in Al-containing solutions for the appropriate length of time, $200-\mu \mathrm{m}$ transverse sections were cut $3 \mathrm{~mm}$ from the apex, placed in planchettes filled with hexadecane, and frozen in a high pressure freezer (Bal-tec HPM010). The high pressure freezing was used to ensure rapid freezing (within milliseconds). Thereafter, the planchettes were split apart and stored under liquid nitrogen before freeze substitution (Leica EM AFS2) in 2\% $(\mathrm{v} / \mathrm{v})$ glutaraldehyde in acetone at $-90^{\circ} \mathrm{C}$ for $48 \mathrm{~h}$, warming to $20^{\circ} \mathrm{C}$, washing in ethanol, infiltration with LR White Resin, and polymerization. After storage at ambient temperature, a Reichert Ultracut Microtome was used to cut $5-\mu \mathrm{m}$ thick sections and placed on $4-\mu \mathrm{m}$ thick Ultralene Film. The sections were cut from within the middle of the $200-\mu \mathrm{m}$ transverse sections in order to avoid any cells that were damaged during cutting of the fresh roots. Previous studies using this technique have shown that cellular contents (including the vacuoles) remain intact during this processing (Kopittke et al., 2015).

The LEXRF measurements were conducted at the TwinMic beamline (BL 1.1L) at ELETTRA, Italy (Gianoncelli et al., 2016) with eight Si-drift detectors in an annular back-scattering configuration positioned around the specimen (Gianoncelli et al., 2009). Selected regions were scanned with $1.7 \mathrm{keV}$ excitation energy with a $0.7 \mu \mathrm{m}$ step size (pixel) and a dwell time of 3-6 s per pixel (longer dwell times were used for samples in which tissue Al concentrations were expected to be lower). Each individual map was $60 \mu \mathrm{m} \times 60 \mu \mathrm{m}(85 \times 85$ pixels $)$ with scans taking $6-12 \mathrm{~h}$ to complete depending upon the dwell time. It was only possible to scan a small proportion of the root cross-sectional area given that the diameter of the root cylinder was ca. $500 \mu \mathrm{m}$. For all six samples, the area selected to be scanned $(60 \mu \mathrm{m} \times 60 \mu \mathrm{m})$ focused on the rhizodermis and outer cortex - this being the area in which Al initially accumulates (Kopittke et al., 2015). The LEXRF spectra were fitted using PyMCA v4.7.3 (Sole et al., 2007).

\section{In Situ Assessment of AI Speciation in Root Tissues}

The speciation of $\mathrm{Al}$ in root tissues was assessed using Al K-edge XANES spectroscopy. Seedlings were grown in solutions with $\mathrm{Ca}$ and $\mathrm{B}$ containing (i) $3.5 \mu \mathrm{M} \mathrm{Al}$ for $48 \mathrm{~h}$ (ES8), (ii) $50 \mu \mathrm{M}$ $\mathrm{Al}$ for $3 \mathrm{~h}$ (ET8), and (iii) $50 \mu \mathrm{M} \mathrm{Al}$ for $48 \mathrm{~h}$ (ET8), yielding a total of three treatments, each with 30 seedlings. (We did not examine ES8 exposed to $3.5 \mu \mathrm{M}$ for $3 \mathrm{~h}$ due to the low tissue $\mathrm{Al}$ concentration.)

Given that it is the apical 3-5 $\mathrm{mm}$ of the root which releases malate (Delhaize et al., 1993b), apical tissues (5 mm) were harvested, frozen in liquid nitrogen, and freeze-dried. The root apices from the 30 seedlings in each treatment were homogenized using a mortar and pestle at room temperature and spread evenly across a piece of double-sided carbon tape on a $\mathrm{Cu}$ holder. The samples were then analyzed in the X-ray absorption 
spectroscopy end-station at the SGM beamline of the Canadian Light Source (Saskatoon, SK, Canada) (Regier et al., 2007). The sample chamber was pumped to $10^{-6}$ Torr and spectra were acquired at the $\mathrm{Al} \mathrm{K}$-edge from 1,550 to $1,600 \mathrm{eV}$ using a $10 \mathrm{~s}$ slew scan (Gillespie et al., 2015). The spectra presented are the average of 60 scans from different regions within each sample as measured in fluorescence with four silicon drift detectors. The spectra were normalized using the ion chamber (I0) spectrum collected simultaneously from an Au mesh in front of the sample and the energy scale calibrated using $\mathrm{AlPO}_{4}$ assuming a value of $1,566.1 \mathrm{eV}$.

Five reference standards were prepared for XANES analysis, being Al-malate, $\gamma-\mathrm{Al}_{2} \mathrm{O}_{3}$ (Alfa Aesar), gibbsite (reagent grade, synthetic, Wards Natural Science), $\mathrm{AlPO}_{4}$ (Sigma-Aldrich, 255963), and Al-pectin. The Al-malate was prepared using stock solutions with $50 \mathrm{mM} \mathrm{AlCl} 3 \cdot 6 \mathrm{H}_{2} \mathrm{O}$ and $200 \mathrm{mM} \mathrm{L}$-malic acid. First, it was noted that a $25 \mathrm{~mL}$ solution with $20 \mathrm{mM} \mathrm{Al}$ and $100 \mathrm{mM}$ L-malic acid (Sigma-Aldrich, 112577) had a $\mathrm{pH}$ of 1.9, and that $3.63 \mathrm{~mL}$ of $1 \mathrm{M} \mathrm{NaOH}$ was required to increase the $\mathrm{pH}$ to 4.5 . Next, a new solution was prepared with the $\mathrm{NaOH}$ added to the L-malic acid prior to the addition of the $\mathrm{Al}$ - this being required to avoid the potential formation of highly toxic polymeric Al when alkali is added to Al-containing solutions (Bertsch and Parker, 1996). After mixing, the solution was frozen in liquid nitrogen and freeze-dried. Modeling with GeoChemEZ (Shaff et al., 2010) indicated that $>99.9 \%$ of the total $\mathrm{Al}$ was complexed with malic acid using the modified stability constants listed by Pellet et al. (1996). The Al-pectin standard was prepared using pectin from citrus fruit (Sigma-Aldrich, P9436). Sufficient $\mathrm{KOH}$ was added to achieve a negative charge of $38 \mu \mathrm{mol} \mathrm{COO}-/ \mathrm{mL}$ (McKenna et al., 2010), with a stock solution of $100 \mathrm{mM} \mathrm{Al}$ added to achieve $100 \%$ saturation. The Al-pectin gel was frozen in liquid nitrogen and freeze-dried.

\section{RESULTS}

\section{Effects of Al on Root Elongation Rate}

Increased $\mathrm{Al}$ concentration in solution decreased RER of wheat seedlings, with the pattern of the response differing markedly between ES8 and ET8 as found by Kikui et al. (2007). Over 48 h, a $50 \%$ decrease in RER of ES8 occurred at $3.5 \mu \mathrm{M}$ Al compared to a concentration of $50 \mu \mathrm{M} \mathrm{Al}$ for ET8, 14-times higher than for ES8 (Figure 1). It is noteworthy that these concentrations caused a slight reduction in RER of both NILs after only $6 \mathrm{~h}$ (Figure 2). The average RER of ES8 after $6 \mathrm{~h}$ exposure to $3.5 \mu \mathrm{M}$ Al was $0.68 \mathrm{~mm} / \mathrm{h}$ compared to $0.93 \mathrm{~mm} / \mathrm{h}$ for the control; corresponding values for ET8 at $50 \mu \mathrm{M} \mathrm{Al}$ for $6 \mathrm{~h}$ were 0.55 and $0.86 \mathrm{~mm} / \mathrm{h}$. For ES8, in particular, exposure to $\mathrm{Al}$ in some treatments resulted in the rupturing and tearing of the outer walls of the rhizodermis (Figure 3).

Six treatments were identified for further investigation: (i, ii) roots of ES8 were exposed for 3 or 48 h to $3.5 \mu \mathrm{M}$ Al (being sufficient to reduce RER slightly after $6 \mathrm{~h}$ and by $50 \%$ after $48 \mathrm{~h}$ ), (iii, iv) roots of ET8 exposed for 3 or $48 \mathrm{~h}$ to $50 \mu \mathrm{M} \mathrm{Al}$ (being sufficient to reduce RER slightly after $6 \mathrm{~h}$ and by $50 \%$ after $48 \mathrm{~h}$ ), and (v, vi) roots of ET8 exposed for 3 or $48 \mathrm{~h}$ to $3.5 \mu \mathrm{M}$

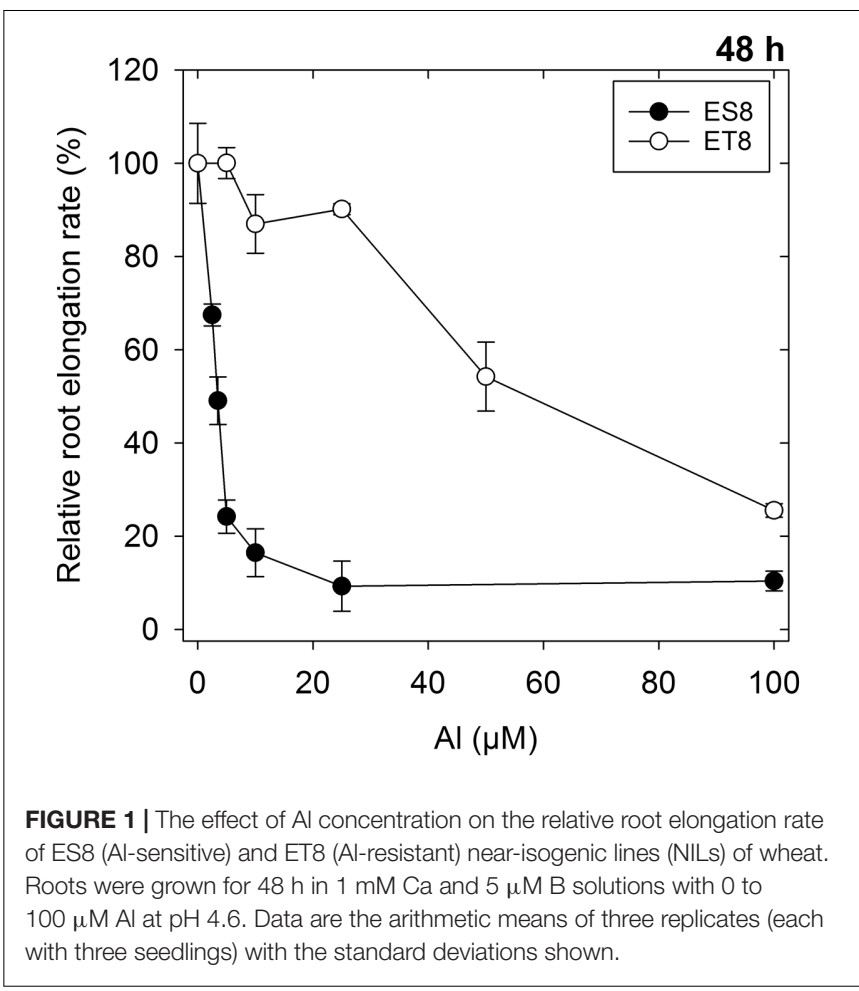

$\mathrm{Al}$ (a concentration that did not decrease the RER of ET8 but decreased the RER of ES 8 by $50 \%$ after $48 \mathrm{~h}$ ). When selecting these treatments, it was noted that the excretion of malate begins rapidly and without any detectable delay (Delhaize et al., 1993b; Osawa and Matsumoto, 2001).

\section{Bulk Concentration of Al in Apical Root Tissues and Root Cation Exchange Capacity}

When grown in solutions containing $\mathrm{Al}$ at a concentration that decreased RER by $50 \%$ over $48 \mathrm{~h}$ (i.e., $3.5 \mu \mathrm{M}$ Al for ES8 and $50 \mu \mathrm{M} \mathrm{Al}$ for ET8), Al in the fresh root apical tissues (i.e., both symplast and apoplast) was ca. four to six times higher for ET8 than for ES8 (Figures 1, 4). However, when ES8 and ET8 were grown at the same $\mathrm{Al}$ concentration, $\mathrm{Al}$ in the root apical tissues was substantially higher for ES8 than for ET8 (Figure 4). For example, when grown in solutions containing $50 \mu \mathrm{M} \mathrm{Al}$, the root tissue $\mathrm{Al}$ concentration was $470 \mu \mathrm{g} / \mathrm{g}$ in ES8 but only $62 \mu \mathrm{g} / \mathrm{g}$ in ET8, with RER being reduced ca. $90 \%$ in ES8 compared to $50 \%$ in ET8.

The observation that the Al concentration was four to six times higher for ET8 than for ES8 (Figure 4) despite the same magnitude of reduction in RER (Figure 1) cannot be attributed to greater CEC in the apical root tissues of ET8 because measurements of CEC using $\mathrm{Cu}$ sorption indicated that the CEC of the root apices was similar in both ES8 and ET8 $\left(0.78 \pm 0.073 \mathrm{mmol}_{+} / \mathrm{kg}\right.$ for ES8 and $0.76 \pm 0.073 \mathrm{mmol}_{+} / \mathrm{kg}$ for ET8 on a fresh mass basis, with standard deviations). 

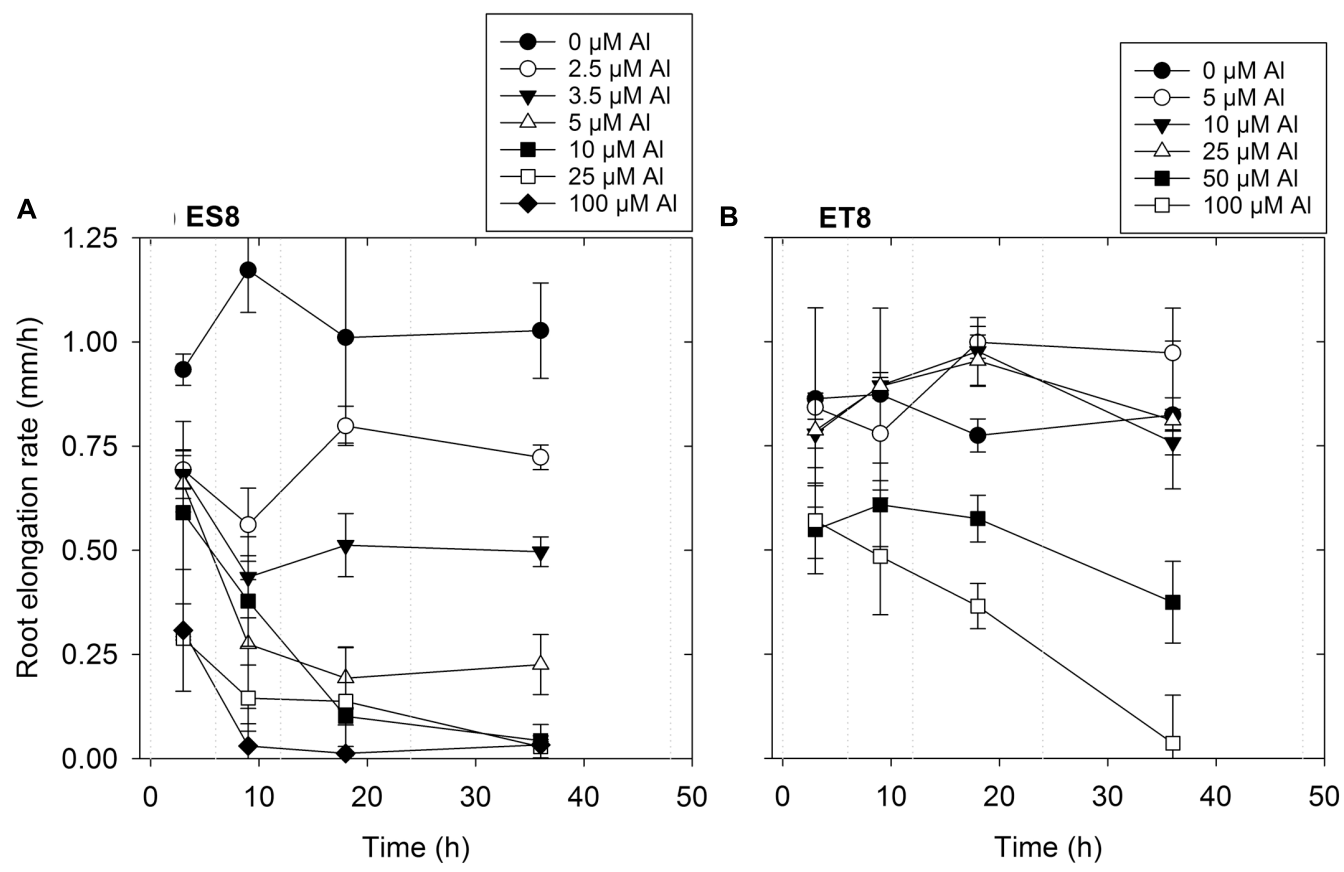

FIGURE 2 | (A,B) Effects of Al on root elongation rate of two NILs of wheat, ES8 and ET8. Measurements of root length were made following exposure to Al for 0, 6 , 12,24 , and $48 \mathrm{~h}$ (as indicated by the vertical dotted lines), with values for root elongation rate displayed mid-way through these periods.

\section{Lateral Distribution of Al in Root Tissues}

In all six treatments, $\mathrm{Al}$ as measured by synchrotron-based LEXRF was highest in the external root tissues, with the concentration decreasing from the rhizodermis through the outer to the inner cortex (Figure 5 and Supplementary Figure 1). Furthermore, $\mathrm{Al}$ accumulated primarily in the cell wall, with comparatively small amounts of $\mathrm{Al}$ within the symplast. Of particular interest is the comparison (Figures $5 \mathbf{A}, \mathbf{B}, \mathbf{E}, \mathbf{F}$ ) between ES8 and ET8 at $\mathrm{Al}$ concentrations causing a similar reduction in growth (i.e., ES8 at $3.5 \mu \mathrm{M} \mathrm{Al}$ and ET8 at $50 \mu \mathrm{M} \mathrm{Al}$ ). It is noteworthy that the distribution of $\mathrm{Al}$ within the rhizodermis and outer cortex was similar - most Al being located within the cell wall in all instances. We also compared ES8 with ET8 when both were grown at $3.5 \mu \mathrm{M}$ - although causing a $50 \%$ reduction in RER of ES8, this $\mathrm{Al}$ concentration does not reduce RER of ET8. Again, the distribution of Al was similar in all four treatments, with most $\mathrm{Al}$ accumulating within the cell wall (Figures 5A-D). However, concentrations of $\mathrm{Al}$ in the walls of the rhizodermis and outer cortex were lower for ET8 than for ES8 exposed to $3.5 \mu \mathrm{M} \mathrm{Al}$, both after 3 and $48 \mathrm{~h}$ exposure (Figures 5A-D).

\section{In Situ Analyses of Al Speciation in Root Apices}

Differences were evident between the Al K-edge XANES spectra of the five standard compounds (Figure 6) with differentiation between six- and four-fold compounds as defined by Ildefonse et al. (1998). Specifically, the spectra of compounds with six-fold coordination environments generally have maxima at ca. 1,568 and $1,572 \mathrm{eV}$ and sometimes have further features at higher energies, while those with four-fold coordination have a strong single maximum at ca. $1,566 \mathrm{eV}$ and only weak features at higher energy. Accordingly, Al-phosphate (four-fold coordinated) had a distinct white-line peak at ca. $1,566 \mathrm{eV}$ and gibbsite (six-fold coordinated) had distinct peaks at 1,567.7 and 1,570.5 eV. With coordination numbers of 4 and $6, \gamma-\mathrm{Al}_{2} \mathrm{O}_{3}$ had distinct peaks at $1,565.8,1,567.1$, and $1,570.5 \mathrm{eV}$.

The Al-malate standard was utilized to examine effects of low molecular weight organic acids commonly produced by plant roots, including those of wheat. The Al-malate standard prepared in this study, with a malate/ $\mathrm{Al}$ molar ratio $(\mathrm{MR})=5$, had a single sharp peak at $1,569.1 \mathrm{eV}$, indicating six-fold coordination. The crystalline Al-malate compounds (malate/Al MR = 1 or 2) investigated by Happel et al. (2007) were also observed to have six-fold coordinated Al. In these cases, the $\mathrm{Al}_{4} \mathrm{O}_{6}$-core was the main structural element, with each $\mathrm{Al}$ coordinated to at least one malate molecule. In another study (Xu et al., 2010), precipitates prepared from solutions with malate/Al MR $=0.001,0.01$ and 0.1 consisted of a mixture of crystalline $\mathrm{Al}$ (oxy)hydroxides and short-ranged ordered (SRO) Al-malates. In this study of Xu et al. (2010), the Al K-edge spectra of the malate/Al MR $=0.001$ and 0.01 precipitates were similar to that of the crystalline $\mathrm{Al}$ (oxy)hydroxides, masking any contribution from the SRO Al-malates. However, the $\mathrm{Al} \mathrm{K-edge}$ spectra of the malate/Al MR $=0.1$ precipitate contained two broad peaks at 1,565.9 eV (four-fold coordination) and 1,570.4 eV (i.e., six-fold coordination). Similar to the Al-malate precipitate prepared in the present study, Xu et al. (2010) found only one maximum for the six-fold coordinated $\mathrm{Al}$ in the malate/Al 

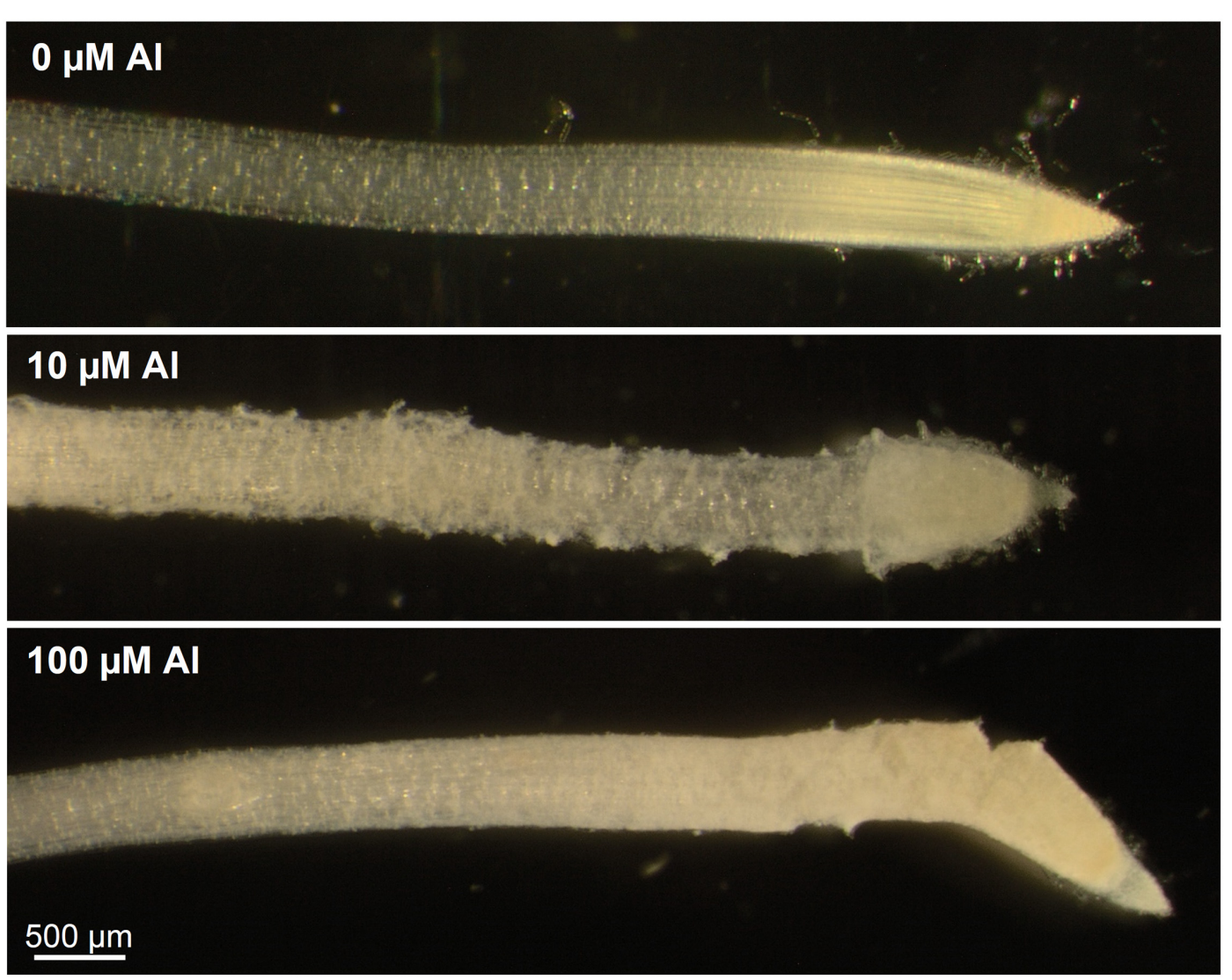

FIGURE 3 | Light micrographs showing roots of ES8 exposed to 0, 10, or $100 \mu \mathrm{M}$ Al for $48 \mathrm{~h}$. Note the tearing and rupturing evident in the outer tissues of roots exposed to 10 or $100 \mu \mathrm{M}$ Al. The scale bar applies to all three images.

$\mathrm{MR}=0.1$ system, suggesting that most of the $\mathrm{Al}$ was bonded to at least one malate molecule. There were also significant amounts of four-fold coordinated $\mathrm{Al}$ as the intensity of the fourfold peak was similar to that of the six-fold peak. Regardless, these results support our hypothesis that most, if not all, of the $\mathrm{Al}$ in the present study was coordinated to malate, given that there was only a single peak in the Al K-edge spectrum for the six-fold coordinated Al (Figure 6). Note that for 'pure' $\mathrm{Al}-\left(\mathrm{O}_{3} \mathrm{PC}_{6} \mathrm{H}_{5}\right)$ complexes (aluminophosphonate), where all $\mathrm{Al}$ is bonded to at least one $-\mathrm{O}_{3} \mathrm{PC}_{6} \mathrm{H}_{5}$ ligand, there are two peaks in the $\mathrm{Al} \mathrm{K}$-edge spectrum for the six-fold coordinated $\mathrm{Al}$, suggesting that only when $\mathrm{C}$ is in the second shell there is not splitting of the six-fold coordinated peak (Chaplais et al., 2001).

A pectin standard was also investigated because polysaccharides are reported to be the main site for $\mathrm{Al}$ sorption in roots (Taylor et al., 2000; Horst et al., 2010). The Al K-edge spectrum for the Al-pectin compound had a low intensity peak at $1,565.3 \mathrm{eV}$ (four-fold coordination) and a single peak at $1,569.0 \mathrm{eV}$ (consistent with a six-fold coordination) that was broader than that for the Al-malate spectrum (Figure 6). The amount of four-fold coordinated $\mathrm{Al}$ was much less than that of the six-fold coordinated $\mathrm{Al}$ as is evident from the weaker intensity of the four-fold $(1,565.3 \mathrm{eV})$

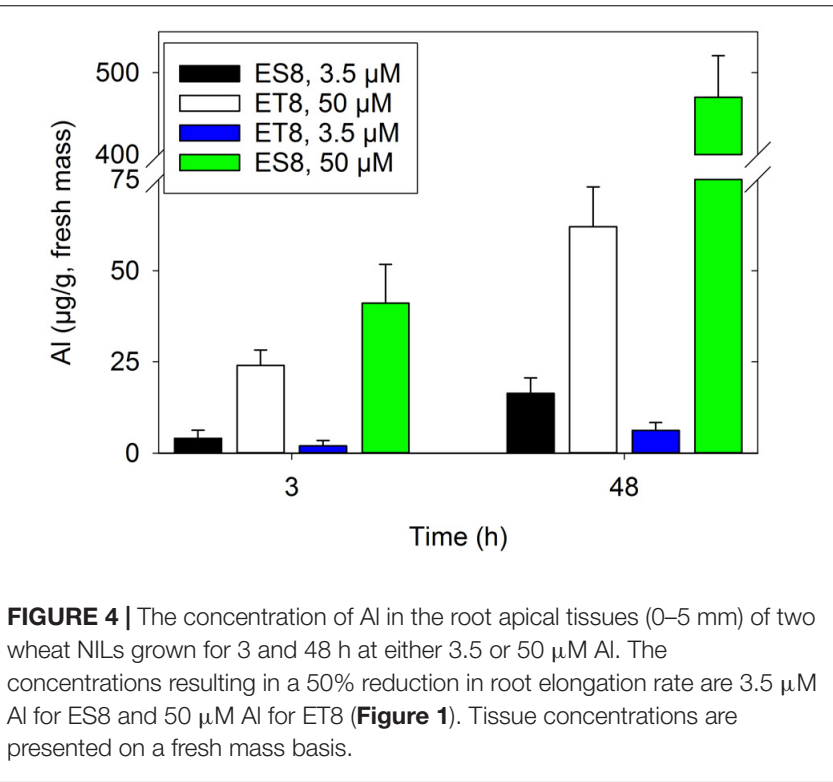

versus six-fold coordinated peak $(1,569.0 \mathrm{eV})$. Thus, it appears that most of the $\mathrm{Al}$ was coordinated to at least one pectin molecule. 

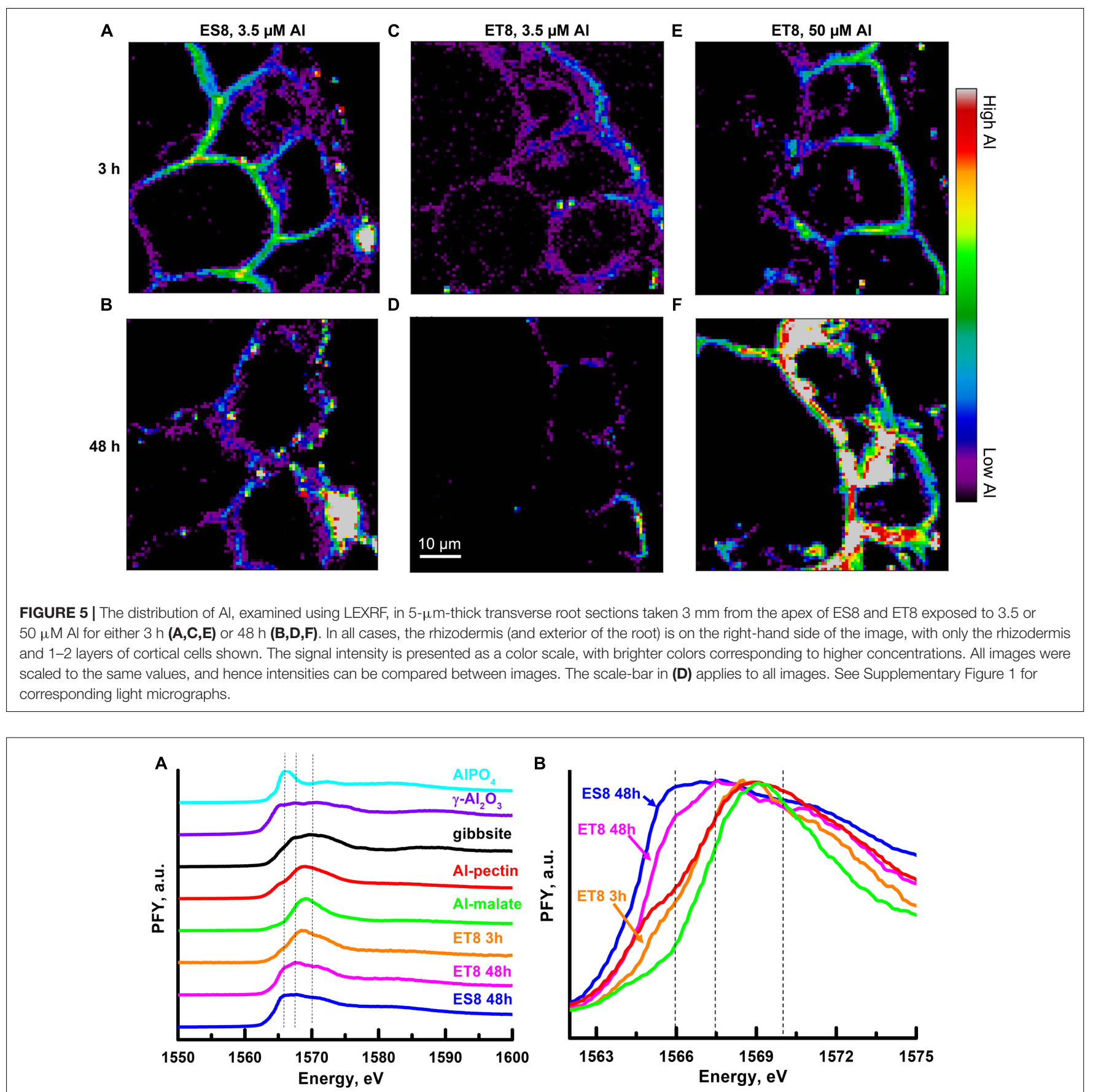

FIGURE 6 | In situ analyses of Al speciation using synchrotron-based X-ray absorption near edge structure (XANES). (A) Al K-edge XANES spectra of five standard compounds and for root tissues of the near-isogenic wheat lines where ET8 was exposed to $50 \mu \mathrm{M}$ Al for 3 or $48 \mathrm{~h}$ and ES8 was exposed to $3.5 \mu \mathrm{M} \mathrm{Al} \mathrm{for} 48 \mathrm{~h}$. (B) Enlarged spectra (1,562-1,575 eV) for the three root tissues and two standards of interest, Al-malate and Al-pectin. The dotted lines are provided for reference, being 1,566 eV (corresponding to the strong single maximum of four-fold coordinated Al, such as for Al-phosphate), 1,567.7 eV (corresponding to the six-fold coordinated peak of gibbsite), and 1,570 eV (corresponding to the six-fold coordinated peak of $\gamma-\mathrm{Al}_{2} \mathrm{O}_{3}$ ).

Next, the Al K-edge XANES spectra of the three root apical samples were examined (Figure 6). Firstly, it should be noted that the spectra from the root samples are not identical to those of the reference compounds, indicating a different $\mathrm{Al}$ environment in the root samples from that of the reference compounds and that $\mathrm{Al}$ coordination is perhaps present as a mixture. Secondly, it was noted that there were clear differences between the spectra of the three samples, depending upon both the time of exposure (comparing ET8 exposed for 3 or $48 \mathrm{~h}$ ) and between NILs (comparing ES8 and ET8 exposed for $48 \mathrm{~h}$ ) 
(Figure 6B). For apices of ET8 exposed for $3 \mathrm{~h}$, the spectrum consisted of a broad peak at 1,568.6 eV (six-fold coordination) with distorted symmetry at higher energy compared to the Al-malate spectrum, and a small peak at $1,565.6 \mathrm{eV}$ (fourfold coordination) with lower intensity than that observed in the Al-pectin spectrum (Figure 6). The six-fold coordinated Al peak was ca. $0.5 \mathrm{eV}$ lower compared to that of the Al-malate and Al-pectin six-fold coordinated Al peak. Thus, it is likely that the $\mathrm{Al}$ in the apices of ET8 exposed for $3 \mathrm{~h}$ is a mixture of $\mathrm{Al}$ species, consisting mainly of $\mathrm{Al}$ organic species, including that of Al-malate, Al-pectin, and perhaps a small contribution from inorganic Al species. For apices of ET8 exposed for $48 \mathrm{~h}$, the spectrum consisted of two peaks at $1,567.7$ and $1,570.3 \mathrm{eV}$ (coordination number of 6) and a peak at $1,566.1 \mathrm{eV}$ (coordination number of 4 ). The presence of a better resolved peak in the ET8 $48 \mathrm{~h}$ spectrum compared to the ET8 $3 \mathrm{~h}$ suggests that there was a slight increase in the inorganic Al species with time. The six-fold maxima occurred nearly $1 \mathrm{eV}$ lower compared to that observed in the ET8 $3 \mathrm{~h}$ spectrum, suggesting that the organic species coordinated to Al were likely changing with time. This could potentially be due to increased polymerization of the organics or $\mathrm{Al}$ ( $\mathrm{Hu}$ et al., 2008). The intensity of the four-fold coordinated Al peak was nearly equal that of the $1,567.7 \mathrm{eV}$ peak, indicating that there was considerably more four-fold coordinated $\mathrm{Al}$ in the ET8 $48 \mathrm{~h}$ tissues compared to the ET8 $3 \mathrm{~h}$ and Al-pectin standard. The spectrum for root apical tissues of ES8 exposed for $48 \mathrm{~h}$ was similar to that of ET8 $48 \mathrm{~h}$ except that the intensity of the four-fold coordinated peak was similar to that of the six-fold maxima in the ET8 $48 \mathrm{~h}$ spectrum (Figure 6). Thus, in summary, XANES analyses indicated clear differences between the three root tissue samples, with $\mathrm{Al}$ in the apices of ET8 exposed for $3 \mathrm{~h}$ being a mixture of $\mathrm{Al}$ species, but mainly $\mathrm{Al}$ organic species including that of Al-malate and Al-pectin.

\section{DISCUSSION}

There is conclusive evidence that organic acid secretion by many plants, including wheat, mitigates the toxic effects of soluble Al by forming harmless complexes (Ma et al., 2001; Ryan et al., 2001; Kochian et al., 2004). However, uncertainty remains as to what extent these complexes form within the root tissue (apoplast and symplast) or in the rhizosphere. We provide evidence that both these processes occur. We utilized synchrotron-based LEXRF to show that $\mathrm{Al}$ (including Al-malate complexes) accumulates largely within the apoplast - this being the dominant compartment of $\mathrm{Al}$-accumulation regardless of treatment. The presence of Al-malate complexes within apoplast protects the root by limiting the binding of $\mathrm{Al}$ to the negatively charged cell wall components which reduces cell elongation and other processes (Horst et al., 2010; Kopittke et al., 2015). It is anticipated that this study will assist in improving plant growth in acid soils high in soluble $\mathrm{Al}$ by improved understanding of the physiological mechanisms of Al resistance.

\section{Al Complexation External to the Root}

Consistent with studies comparing sensitive and resistant cultivars of wheat (Rincón and Gonzales, 1992; Delhaize et al., 1993b; Kikui et al., 2007), ET8 accumulated substantially less Al in the apical root tissues (apoplast and symplast) than did ES8 when grown at the same $\mathrm{Al}$ concentration in solution (Figure 4). This was not due to differences in the CEC of root apical tissues since these were similar at $0.78 \mathrm{mmol}_{+} / \mathrm{kg}$ for ES8 and 0.76 $\mathrm{mmol}_{+} / \mathrm{kg}$ for ET8. Rather, the data indirectly confirms the importance of malate secretion into the rhizosphere where it complexes $\mathrm{Al}$ causing a substantial reduction in the entry of $\mathrm{Al}$ into the root tissue.

\section{Al Complexation within the Root}

Not only is Al complexed by malate external to ET8 roots (as shown by decreased tissue concentrations when grown at the same $\mathrm{Al}$ in the rooting medium as ES8), some of the Al within the root itself is complexed by malate - this being evidenced by two observations. Firstly, when ES8 and ET8 were exposed to sufficient $\mathrm{Al}$ to reduce RER by $50 \%$ over $48 \mathrm{~h}(3.5 \mu \mathrm{M} \mathrm{Al}$ for ES8 and $50 \mu \mathrm{M}$ for ET8, Figure 1), the apical root tissues of ET8 accumulated four to six times more Al than did those of ES8 (Figure 4). This difference in Al-accumulation could not be attributed to differences in the negative charge of the root tissues. This finding is similar to that reported by Kikui et al. (2007), who found that ET8 accumulated two to three times more Al in apical $(10 \mathrm{~mm})$ root tissues than did ES8 when grown at differing $\mathrm{Al}$ concentrations resulting in a comparable reduction in RER. Secondly, in situ synchrotron-based XANES analysis showed that $\mathrm{Al}$ was six-fold coordinated within $5 \mathrm{~mm}$ apical tissues of ET8 roots exposed to $\mathrm{Al}$ for $3 \mathrm{~h}$, with the relatively sharp peak in the XANES spectrum $(1,568.6 \mathrm{eV})$ indicating the likely presence of Al-malate together with other six-fold coordinated Al such as Al-pectin (Figure 6). After exposure to $\mathrm{Al}$ for $48 \mathrm{~h}$, much of the Al was four-fold coordinated (particularly for ES8, with ET8 still having a higher proportion of six-fold coordinated Al), although the exact form of this four-fold coordinated Al is not clear and further work is required. To our knowledge, this is the first time that XANES analyses have been used to examine the speciation of $\mathrm{Al}$ within plant tissues (see review by Kopittke et al., 2016).

Given that Al-malate complexes were present within the root tissues, we utilized synchrotron-based LEXRF to examine the distribution of $\mathrm{Al}$ in transverse sections cut $3 \mathrm{~mm}$ from the apex. In contrast to morin, a fluorochrome that forms a fluorescent complex with $\mathrm{Al}$ (Eticha et al., 2005b), for example, LEXRF is able to detect all $\mathrm{Al}$ within plant tissues, including Al bound to the cell wall. In accordance with measurements of bulk concentrations (Figure 4), the LEXRF analyses indicated that when ES8 and ET8 were grown at $3.5 \mu \mathrm{M} \mathrm{Al}$, roots of ES8 accumulated more $\mathrm{Al}$ than did those of ET8 (as is evident when comparing Figures 5A,B with Figures 5C,D). However, when grown at $\mathrm{Al}$ concentrations that resulted in the same reduction in RER, root tissues of ET8 tended to accumulate more $\mathrm{Al}$ than did those of ES8 (Figure 4, and compare Figures 5A,B with Figures $\mathbf{5 E}, \mathbf{F}$ ). The concentration of $\mathrm{Al}$ was highest in the 
rhizodermis in all six treatments, decreasing in the outer cortical tissues and even more so in the inner cortex. Furthermore, Al accumulated primarily in the cell wall in apical root tissues of both ES8 and ET8, with comparatively small amounts of Al found within the symplast (Figure 5) as found by Taylor et al. (2000). This indicates that $\mathrm{Al}$ complexed by malate within the root tissues of ET8 accumulated primarily within the apoplast of the rhizodermis and outer cortex.

It is noteworthy that roots, particularly for ES8, ruptured when exposed to high concentrations of Al (Figure 3) - this having been observed previously in the roots of a wide range of plant species (Ryan et al., 1993; Yamamoto et al., 2001; Kopittke et al., 2008; Motoda et al., 2010; Osawa et al., 2011). These ruptures form initially in the elongation zone due to the "differential expansion between Al-arrested epidermis cells and (the) still-expanding cortex cells" (Osawa et al., 2011). Interestingly, it is in these that are susceptible to rupturing (i.e., the rhizodermis and outer cortex) that $\mathrm{Al}$ was found to accumulate to high concentrations (Figure 5). This reaffirms the importance of $\mathrm{Al}$ accumulation in the cell walls, thereby decreasing root elongation by rapidly inhibiting the ability of the walls to loosen (Kopittke et al., 2015). Thus, it is apparent that the complexation of Al by malate in ET8, both in the rhizosphere and apoplast, reduces the strong binding of $\mathrm{Al}$ to the cell wall, and thereby reduces the damaging interactions of $\mathrm{Al}$ with the root cells.

The observation in the present study that $\mathrm{Al}$ is complexed by malate within the root tissues is in agreement with the theoretical modeling of Kinraide et al. (2005) who concluded that resistance to Al could not result solely from the secretion of malate into the rhizosphere with a concomitant reduction in $\mathrm{Al}^{3+}$ activity at the root surface. Our findings are also supported by those of Kikui et al. (2007) that much of the $\mathrm{Al}$ in the apical $0-4 \mathrm{~mm}$ of ET8 roots (but not of ES8 roots) was removed by rinsing with citrate, suggesting that $\mathrm{Al}$ in root tissues of ET8 is not bound strongly to the cell wall. Additionally, Zheng et al. (2004) concluded that the production of organic acids and subsequent formation of Al-organic complexes would likely reduce the binding strength of Al within the apoplast.

Finally, we can make some conclusion about whether the Al-malate complexes in root tissues are formed in planta or whether they are formed in the rhizosphere first and then penetrate the tissue. We know that the Al concentrations in ES8 and ET8 tissues are markedly higher in solutions containing uncomplexed $\mathrm{Al}$ than when $\mathrm{Al}$ is complexed with malate. For example, Kikui et al. (2007) reported that root apical tissues of ES8 exposed to $5 \mu \mathrm{M} \mathrm{Al}$ contained $0.31 \mathrm{nmol} \mathrm{Al} /$ apex but decreased to $0.15 \mathrm{nmol} \mathrm{Al}$ /apex when exposed to $50 \mu \mathrm{M} \mathrm{Al}$ with $100 \mu \mathrm{M}$ malate (i.e., $\mathrm{Al}$ in the apex was halved despite a 10 -fold increase in solution $\mathrm{Al}$ ). We also showed here that the ES8 roots accumulate more Al than ET8 roots when exposed to the same Al concentration. Presumably this marked decrease in the presence of malate in ET8 occurs because the Al triggers the release of malate from the ET8 roots. While the trivalent $\mathrm{Al}^{3+}$ binds strongly to cell walls and hence accumulates rapidly in ES8 roots, the Al-malate complex does not. Tian et al. (2014) have shown similar results as have Blamey et al. (1997) with pectic complexes. In the present study also, root apical tissues of ET8 contained four-fold to six-fold more Al than did those of ES8 when exposed to Al concentrations causing a $50 \%$ reduction in RER (Figure 4) suggesting that the Almalate complexes are formed in planta, rather than being taken up from the rhizosphere. However, further studies are required to test this hypothesis. Regardless of whether the Al-malate complexes within the apoplast form within the root or within the rhizosphere, it is known that Al-malate complexes are non-toxic (or at the least, substantially less toxic) than is the free $\mathrm{Al}^{3+}$ ion (Kerven et al., 1991; Ryan et al., 1995b; Pellet et al., 1996). In addition, previous studies have reported that organic acids (such as citrate or malate) are able to desorb $\mathrm{Al}$ from cell walls (Zhang and Taylor, 1990). This suggests that the release of malate into the apoplast could possibly detoxify apoplastic $\mathrm{Al}$, even after it had initially bound to the cell wall.

\section{CONCLUSION}

Although it is commonly assumed that $\mathrm{Al}$ is detoxified by the release of organic anions (such as malate) into the rhizosphere, the present study has shown that a substantial amount of the Al within root apices of the Al-resistant wheat NIL, ET8, is present as Al-malate complexes. We utilized synchrotron-based XANES to provide in situ information regarding the speciation of $\mathrm{Al}$ within apical root tissues. Furthermore, synchrotron-based LEXRF analyses demonstrated that $\mathrm{Al}$ (including any Al-malate complexes) accumulated predominantly within the apoplast of the rhizodermis and outer cortex thereby limiting the strong binding of $\mathrm{Al}^{3+}$ to cell wall components. The information obtained in the present study is important in developing an understanding of the underlying physiological mode of action whereby organic anions allow for improved growth in Al-toxic systems.

\section{AUTHOR CONTRIBUTIONS}

PK, NM, PR, and PW conceived the research program; PK, BM, and $\mathrm{KG}$ conducted the plant-growth experiments; PK, BM, AG, GK, and FB conducted LEXRF analyses at Elettra (Italy); PK, $\mathrm{BM}, \mathrm{CK}, \mathrm{JD}$, and ZA conducted the analyses at the Canadian Light Source; PK, BM, PW, and FB carried out the data analyses; PK wrote the first draft of the article to which all other authors contributed.

\section{FUNDING}

PK is the recipient of an Australian Research Council (ARC) Future Fellowship (FT120100277) and PW is the recipient of an ARC Discovery Early Career Researcher Award (DE130100943). We acknowledge travel funding provided by the International Synchrotron Access Program (ISAP) (AS/IA161/10724 and 
AS/IA162/11494) managed by the Australian Synchrotron and funded by the Australian Government. Parts of the research described in this paper were performed at the Canadian Light Source, which is supported by the Canada Foundation for Innovation, Natural Sciences and Engineering Research Council of Canada, the University of Saskatchewan, the Government of Saskatchewan, Western Economic Diversification Canada, the National Research Council Canada, and the Canadian Institutes of Health Research. The LEXRF analyses were conducted at the TwinMic beamline of Elettra Sincrotrone Trieste (Trieste, Italy).

\section{REFERENCES}

Bennet, R. J., Breen, C. M., and Bandu, V. (1985). Aluminum toxicity and regeneration of the root cap - Preliminary evidence for a Golgi-apparatus derived morphogen in the primary root of Zea mays. S. Afr. J. Bot. 51, 363-370. doi: 10.1016/S0254-6299(16)31644-1

Bertsch, P. M., and Parker, D. R. (1996). “Aqueous polynuclear aluminum species”, in The Environmental Chemistry of Aluminum, 2nd Edn, ed. G. Sposito (Boca Raton, FL: CRC/Lewis Publishers), 464.

Blamey, F. P. C., Ostatek-Boczynski, Z., and Kerven, G. L. (1997). Ligand effects on aluminium sorption by calcium pectate. Plant Soil 149, 87-94. doi: 10.1007/ BF00010765

Blamey, F. P. C., Wehr, J. B., Wang, P., Menzies, N. W., and Kopittke, P. M. (2014). Kinetics and mechanisms of cowpea root adaptation to changes in solution calcium. Plant Soil 379, 301-314. doi: 10.1007/s11104-014-2065-1

Chaplais, G., Prouzet, E., Flank, A.-M., and Le Bideau, J. (2001). 27Al MAS NMR and XAS cross-study of the aluminophosphonate $\mathrm{Al}(\mathrm{OH})(\mathrm{O} 3 \mathrm{PC} 6 \mathrm{H} 5)$. New J. Chem. 25, 1365-1367. doi: 10.1039/B106545A

Cosgrove, D. J. (1989). Characterization of long-term extension of isolated cell walls from growing cucumber hypocotyls. Planta 177, 121-130. doi: 10.1007/ BF00392162

de Andrade, L. R. M., Ikeda, M., Velho do Amaral, L. I., and Ishizuka, J. (2011). Organic acid metabolism and root excretion of malate in wheat cultivars under aluminium stress. Plant Physiol. Biochem. 49, 55-60. doi: 10.1016/j.plaphy.2010. 09.023

Delhaize, E., Craig, S., Beaton, C. D., Bennet, R. J., Jagadish, V. C., and Randall, P. J. (1993a). Aluminum tolerance in wheat (Triticum aestivum L) 1. Uptake and distribution of aluminum in root apices. Plant Physiol. 103, 685-693.

Delhaize, E., Ryan, P. R., and Randall, P. J. (1993b). Aluminum tolerance in wheat (Triticum aestivum L.) 2. Aluminum-stimulated excretion of malic acid from root apices. Plant Physiol. 103, 695-702.

Delhaize, E., Gruber, B. D., and Ryan, P. R. (2007). The roles of organic anion permeases in aluminium resistance and mineral nutrition. FEBS Lett. 581, 2255-2262. doi: 10.1016/j.febslet.2007.03.057

Doncheva, S., Amenos, M., Poschenrieder, C., and Barcelo, J. (2005). Root cell patterning: a primary target for aluminium toxicity in maize. J. Exp. Bot. 56, 1213-1220. doi: 10.1093/jxb/eri115

Eswaran, H., Reich, P., and Beinroth, F. (1997). "Global distribution of soils with acidity," in Plant-Soil Interactions at Low pH, ed. A. C. Moniz (Sao Paulo: Brazilian Soil Science Society), 159-164.

Eticha, D., Stass, A., and Horst, W. J. (2005a). Cell-wall pectin and its degree of methylation in the maize root-apex: significance for genotypic differences in aluminium resistance. Plant Cell Environ. 28, 1410-1420. doi: 10.1111/j.13653040.2005.01375.x

Eticha, D., Stass, A., and Horst, W. J. (2005b). Localization of aluminium in the maize root apex: can morin detect cell wall-bound aluminium? J. Exp. Bot. 56, 1351-1357. doi: 10.1093/jxb/eri136

Garcia-Oliveira, A. L., Martins-Lopes, P., Tolrá, R., Poschenrieder, C., Tarquis, M., Guedes-Pinto, H., et al. (2014). Molecular characterization of the citrate transporter gene TaMATE1 and expression analysis of upstream genes involved in organic acid transport under Al stress in bread wheat (Triticum aestivum). Physiol. Plant. 152, 441-452. doi: 10.1111/ppl.12179

Gianoncelli, A., Kaulich, B., Alberti, R., Klatka, T., Longoni, A., de Marco, A., et al. (2009). Simultaneous soft X-ray transmission and emission

\section{ACKNOWLEDGMENT}

Seeds of ES8 and ET8 were generously supplied by Dr. Delhaize (CSIRO, Australia).

\section{SUPPLEMENTARY MATERIAL}

The Supplementary Material for this article can be found online at: http://journal.frontiersin.org/article/10.3389/fpls.2017.01377/ full\#supplementary-material

microscopy. Nucl. Instrum. Methods 608, 195-198. doi: 10.1016/j.nima.2009. 06.035

Gianoncelli, A., Kourousias, G., Merolle, L., Altissimo, M., and Bianco, A. (2016). Current status of the TwinMic beamline at Elettra: a soft X-ray transmission and emission microscopy station. J. Synchrotron. Radiat. 23, 1526-1537. doi: 10.1107/S1600577516014405

Gillespie, A. W., Phillips, C. L., Dynes, J. J., Chevrier, D., Regier, T. Z., and Peak, D. (2015). "Chapter One - Advances in using soft X-ray spectroscopy for measurement of soil biogeochemical processes," in Advances in Agronomy, ed. L. S. Donald (Cambridge, MA: Academic Press), 1-32.

Happel, O., Harms, K., and Seubert, A. (2007). Synthesis and structural characterization of two aluminium malate complexes. Z. Anorg. Allg. Chem. 633, 1952-1958. doi: 10.1002/zaac.200700241

Horst, W. J., Wang, Y., and Eticha, D. (2010). The role of the root apoplast in aluminium-induced inhibition of root elongation and in aluminium resistance of plants: a review. Ann. Bot. 106, 185-197. doi: 10.1093/aob/mcq053

Hu, Y. F., Xu, R. K., Dynes, J. J., Blyth, R. I. R., Yu, G., Kozak, L. M., et al. (2008). Coordination nature of aluminum (oxy)hydroxides formed under the influence of tannic acid studied by X-ray absorption spectroscopy. Geochim. Cosmochim. Acta 72, 1959-1969. doi: 10.1016/j.gca.2008.02.002

Ildefonse, P., Cabaret, D., Sainctavit, P., Calas, G., Flank, A. M., and Lagarde, P. (1998). Aluminium X-ray absorption near edge structure in model compounds and Earth's surface minerals. Phys. Chem. Miner. 25, 112-121. doi: 10.1007/ s002690050093

Jones, D. L., Blancaflor, E. B., Kochian, L. V., and Gilroy, S. (2006). Spatial coordination of aluminium uptake, production of reactive oxygen species, callose production and wall rigidification in maize roots. Plant Cell Environ. 29, 1309-1318. doi: 10.1111/j.1365-3040.2006.01509.x

Kaulich, B., Gianoncelli, A., Beran, A., Eichert, D., Kreft, I., Pongrac, P., et al. (2009). Low-energy X-ray fluorescence microscopy opening new opportunities for bio-related research. J. R. Soc. Interface 6(Suppl. 5), S641-S647. doi: 10.1098/ rsif.2009.0157.focus

Kerven, G. L., Asher, C. J., Edwards, D. G., and Ostatek-Boczynski, Z. (1991). Sterile solution culture techniques for aluminium toxicity studies involving organic acids. J. Plant Nutr. 14, 975-985. doi: 10.1080/019041691093 64257

Kikui, S., Sasaki, T., Osawa, H., Matsumoto, H., and Yamamoto, Y. (2007). Malate enhances recovery from aluminum-caused inhibition of root elongation in wheat. Plant Soil 290, 1-15. doi: 10.1007/s11104-006-9068-5

Kinraide, T. B., Parker, D. R., and Zobel, R. W. (2005). Organic acid secretion as a mechanism of aluminium resistance: a model incorporating the root cortex, epidermis, and the external unstirred layer. J. Exp. Bot. 56, 1853-1865. doi: 10.1093/jxb/eri175

Kochian, L. V., Hoekenga, O. A., and Pineros, M. A. (2004). How do crop plants tolerate acid soils? - Mechanisms of aluminum tolerance and phosphorous efficiency. Annu. Rev. Plant Biol. 55, 459-493. doi: 10.1146/annurev.arplant.55. 031903.141655

Kopittke, P. M., Blamey, F. P. C., and Menzies, N. W. (2008). Toxicities of soluble $\mathrm{Al}, \mathrm{Cu}$, and $\mathrm{La}$ include ruptures to rhizodermal and root cortical cells of cowpea. Plant Soil 303, 217-227. doi: 10.1007/s11104-007-9500-5

Kopittke, P. M., Menzies, N. W., de Jonge, M. D., McKenna, B. A., Donner, E., Webb, R. I., et al. (2011). In situ distribution and speciation of toxic $\mathrm{Cu}, \mathrm{Ni}$ and $\mathrm{Zn}$ in hydrated roots of cowpea. Plant Physiol. 156, 663-673. doi: 10.1104/pp. 111.173716 
Kopittke, P. M., Menzies, N. W., Wang, P., and Blamey, F. P. C. (2016). Kinetics and location of aluminium rhizotoxic effects: a review. J. Exp. Bot. 67, 4451-4467. doi: 10.1093/jxb/erw233

Kopittke, P. M., Moore, K. L., Lombi, E., Gianoncelli, A., Ferguson, B. J., Blamey, F. P. C., et al. (2015). Identification of the primary lesion of toxic aluminum (Al) in plant roots. Plant Physiol. 167, 1402-1411. doi: 10.1104/pp.114.253229

Lindsay, W. L. (1979). Chemical Equilibria in Soils. New York, NY: John Wiley \& Sons.

Ma, J. F., Hiradate, S., Nomoto, K., Iwashita, T., and Matsumoto, H. (1997a). Internal detoxification mechanism of $\mathrm{Al}$ in Hydrangea (identification of $\mathrm{Al}$ form in the leaves). Plant Physiol. 113, 1033-1039. doi: 10.1104/pp.113.4.1033

Ma, J. F., Zheng, S. J., Matsumoto, H., and Hiradate, S. (1997b). Detoxifying aluminium with buckwheat. Nature 390, 569-570.

Ma, J. F., Ryan, P. R., and Delhaize, E. (2001). Aluminium tolerance in plants and the complexing role of organic acids. Trends Plant Sci. 6, 273-278. doi: 10.1016/s1360-1385(01)01961-6

McKenna, B. A., Nicholson, T. M., Wehr, J. B., and Menzies, N. W. (2010). Effects of $\mathrm{Ca}, \mathrm{Cu}, \mathrm{Al}$ and $\mathrm{La}$ on pectin gel strength: implications for plant cell walls. Carbohydr. Res. 345, 1174-1179. doi: 10.1016/j.carres.2010.03.044

Meychik, N., Nikolaeva, Y., Kushunina, M., and Yermakov, I. (2014). Are the carboxyl groups of pectin polymers the only metal-binding sites in plant cell walls? Plant Soil 381, 25-34. doi: 10.1007/s11104-014-2111-z

Motoda, H., Kano, Y., Hiragami, F., Kawamura, K., and Matsumoto, H. (2010). Morphological changes in the apex of pea roots during and after recovery from aluminium treatment. Plant Soil 333, 49-58. doi: 10.1007/s11104-010-0318-1

Osawa, H., Endo, I., Hara, Y., Matsushima, Y., and Tange, T. (2011). Transient proliferation of proanthocyanidin-accumulating cells on the epidermal apex contributes to highly aluminum-resistant root elongation in camphor tree. Plant Physiol. 155, 433-446. doi: 10.1104/pp.110.166967

Osawa, H., and Matsumoto, H. (2001). Possible involvement of protein phosphorylation in aluminum-responsive malate efflux from wheat root apex. Plant Physiol. 126, 411-420. doi: 10.1104/pp.126.1.411

Pellet, D. M., Papernik, L. A., and Kochian, L. V. (1996). Multiple aluminumresistance mechanisms in wheat (roles of root apical phosphate and malate exudation). Plant Physiol. 112, 591-597. doi: 10.1104/pp.112.2.591

Regier, T., Krochak, J., Sham, T. K., Hu, Y. F., Thompson, J., and Blyth, R. I. R. (2007). Performance and capabilities of the Canadian Dragon: the SGM beamline at the Canadian light source. Nucl. Instrum. Methods A 582, 93-95. doi: 10.1016/j.nima.2007.08.071

Rincón, M., and Gonzales, R. A. (1992). Aluminum partitioning in intact roots of aluminum-tolerant and aluminum-sensitive wheat (Triticum aestivum L.) cultivars. Plant Physiol. 99, 1021-1028. doi: 10.1104/pp.99.3.1021

Ryan, P. R., Delhaize, E., and Jones, D. L. (2001). Function and mechanism of organic anion exudation from plant roots. Annu. Rev. Plant Physiol. Plant Mol. Biol. 52, 527-560. doi: 10.1146/annurev.arplant.52.1.527

Ryan, P. R., Delhaize, E., and Randall, P. J. (1995a). Characterisation of Al-stimulated efflux of malate from the apices of Al-tolerant wheat roots. Planta 196, 103-110. doi: 10.1007/BF00193223

Ryan, P. R., Delhaize, E., and Randall, P. J. (1995b). Malate efflux from root apices and tolerance to aluminium are highly correlated in wheat. Aust. J. Plant Physiol. 22, 531-536. doi: 10.1071/PP9950531

Ryan, P. R., Ditomaso, J. M., and Kochian, L. V. (1993). Aluminium toxicity in roots: an investigation of spatial sensitivity and the role of the root cap. J. Exp. Bot. 44, 437-446. doi: 10.1093/jxb/44.2.437

Ryan, P. R., Raman, H., Gupta, S., Horst, W. J., and Delhaize, E. (2009). A second mechanism for aluminum resistance in wheat relies on the constitutive efflux of citrate from roots. Plant Physiol. 149, 340-351. doi: 10.1104/pp.108.129155

Schmohl, N., Pilling, J., Fisahn, J., and Horst, W. J. (2000). Pectin methylesterase modulates aluminium sensitivity in Zea mays and Solanum tuberosum. Physiol. Plant. 109, 419-427. doi: 10.1034/j.1399-3054.2000.100408.x

Shaff, J. E., Schultz, B. A., Craft, E. J., Clark, R. T., and Kochian, L. V. (2010). GEOCHEM-EZ: a chemical speciation program with greater power and flexibility. Plant Soil 330, 207-214. doi: 10.1007/s11104-009-0193-9

Sole, V. A., Papillon, E., Cotte, M., Walter, P., and Susini, J. (2007). A multiplatform code for the analysis of energy-dispersive X-ray fluorescence spectra. Spectrochim. Acta Part B At. Spectrosc. 62, 63-68. doi: 10.1016/j.sab.2006.12.002

Taylor, G. J. (1991). Current views of the aluminum stress response: the physiological basis of tolerance. Curr. Top. Plant Biochem. Physiol. 10, 57-93.
Taylor, G. J., McDonald-Stephens, J. L., Hunter, D. B., Bertsch, P. M., Elmore, D., Rengel, Z., et al. (2000). Direct measurement of aluminum uptake and distribution in single cells of Chara corallina. Plant Physiol. 123, 987-996. doi: 10.1104/pp.123.3.987

Tian, Q., Zhang, X., Gao, Y., Bai, W., Ge, F., Ma, Y., et al. (2013). Wheat genotypes differing in aluminum tolerance differ in their growth response to CO2 enrichment in acid soils. Ecol. Evol. 3, 1440-1448. doi: 10.1002/ece3.559

Tian, Q., Zhang, X., Ramesh, S., Gilliham, M., Tyerman, S. D., and Zhang, W.-H. (2014). Ethylene negatively regulates aluminium-induced malate efflux from wheat roots and tobacco cells transformed with TaALMT1. J. Exp. Bot. 65, 2415-2426. doi: 10.1093/jxb/eru123

von Uexküll, H. R., and Mutert, E. (1995). Global extent, development and economic impact of acid soils. Plant Soil 171, 1-15. doi: 10.1007/BF00009558

Xia, J., Yamaji, N., Kasai, T., and Ma, J. F. (2010). Plasma membranelocalized transporter for aluminum in rice. Proc. Natl. Acad. Sci. U.S.A. 107, 18381-18385. doi: 10.1073/pnas.1004949107

Xu, R. K., Hu, Y. F., Dynes, J. J., Zhao, A. Z., Blyth, R. I. R., Kozak, L. M., et al. (2010). Coordination nature of aluminum (oxy)hydroxides formed under the influence of low molecular weight organic acids and a soil humic acid studied by X-ray absorption spectroscopy. Geochim. Cosmochim. Acta 74, 6422-6435. doi: 10.1016/j.gca.2010.07.029

Yamamoto, Y., Kobayashi, Y., Devi, S. R., Rikiishi, S., and Matsumoto, H. (2002). Aluminum toxicity is associated with mitochondrial dysfunction and the production of reactive oxygen species in plant cells. Plant Physiol. 128, 63-72. doi: 10.1104/pp.010417

Yamamoto, Y., Kobayashi, Y., and Matsumoto, H. (2001). Lipid peroxidation is an early symptom triggered by aluminum, but not the primary cause of elongation inhibition in pea roots. Plant Physiol. 125, 199-208. doi: 10.1104/pp.125.1.199

Yang, J. L., Li, Y. Y., Zhang, Y. J., Zhang, S. S., Wu, Y. R., Wu, P., et al. (2008). Cell wall polysaccharides are specifically involved in the exclusion of aluminum from the rice root apex. Plant Physiol. 146, 602-611. doi: 10.1104/pp.107.111989

Yang, J. L., Zhu, X. F., Peng, Y. X., Zheng, C., Li, G. X., Liu, Y., et al. (2011). Cell wall hemicellulose contributes significantly to aluminum adsorption and root growth in Arabidopsis. Plant Physiol. 155, 1885-1892. doi: 10.1104/pp.111. 172221

Zhang, G., and Taylor, G. J. (1990). Kinetics of aluminum uptake in Triticum aestivum L: identity of the linear phase of aluminum uptake by excised roots of aluminum-tolerant and aluminum-sensitive cultivars. Plant Physiol. 94, 577-584. doi: 10.1104/pp.94.2.577

Zheng, S., Lin, X., Yang, J., Liu, Q., and Tang, C. (2004). The kinetics of aluminum adsorption and desorption by root cell walls of an aluminum resistant wheat (Triticum aestivum L.) cultivar. Plant Soil 261, 85-90. doi: 10.1023/B:PLSO. $0000035576.71760 .2 \mathrm{~b}$

Zhu, X. F., Shi, Y. Z., Lei, G. J., Fry, S. C., Zhang, B. C., Zhou, Y. H., et al. (2012). $\mathrm{XTH} 31$, Encoding an in vitro XEH/XET-active enzyme, regulates aluminum sensitivity by modulating in vivo XET action, cell wall xyloglucan content, and aluminum binding capacity in Arabidopsis. Plant Cell 24, 4731-4747. doi: 10.1105/tpc.112.106039

Zhu, X. F., Sun, Y., Zhang, B. C., Mansoori, N., Wan, J. X., Liu, Y., et al. (2014). TRICHOME BIREFRINGENCE-LIKE27 affects aluminum sensitivity by modulating the $\mathrm{O}$-acetylation of xyloglucan and aluminum-binding capacity in Arabidopsis. Plant Physiol. 166, 181-189. doi: 10.1104/pp.114.243808

Conflict of Interest Statement: The authors declare that the research was conducted in the absence of any commercial or financial relationships that could be construed as a potential conflict of interest.

The reviewer AATJ and handling Editor declared their shared affiliation, and the handling Editor states that the process nevertheless met the standards of a fair and objective review.

Copyright (C) 2017 Kopittke, McKenna, Karunakaran, Dynes, Arthur, Gianoncelli, Kourousias, Menzies, Ryan, Wang, Green and Blamey. This is an open-access article distributed under the terms of the Creative Commons Attribution License (CC BY). The use, distribution or reproduction in other forums is permitted, provided the original author(s) or licensor are credited and that the original publication in this journal is cited, in accordance with accepted academic practice. No use, distribution or reproduction is permitted which does not comply with these terms. 